\title{
TORQUE, POWER AND FATIGUE RATIO IN KNEE FLEXORS AND EXTENSORS OF SOCCER PLAYERS
}

\author{
ÍNDICE DE TORQUE, POTÊNCIA E FADIGA NOS FLEXORES E EXTENSORES DO JOELHO DE JOGADORES \\ DEFUTEBOL
}

Original Article

ARTIGO ORIGINAL

Artículo Original

\author{
ÍNDICE DE PAR DE TORSIÓN, POTENCIA Y FATIGA EN LOS FLEXORES Y EXTENSORES DE LA RODILLA \\ DEJUGADORES DEFÚTBOL
}

\author{
Jamilson Simões Brasileiro' \\ (Physiotherapist) \\ Liane de Brito Macedo \\ (Physiotherapist) \\ Araken Kleber Azevedo de Oliveira' \\ (Physiotherapist) \\ Caio Alano de Almeida Lins \\ (Physiotherapist)

\section{Universidade Federal do} \\ Rio Grande do Norte (UFRN), \\ Department of Physical Therapy, \\ Laboratório de Análise da \\ Performance Neuromuscular \\ Laboratório de Análise da \\ Performance Neuromuscular \\ (LAPERN), Natal, RN, Brazil.
}

\section{Correspondence:}

Universidade Federal do Rio Grande do Norte. Departamento de

Fisioterapia. Av. Senador Salgado

Filho, 3000, Campus Universitário,

Lagoa Nova, Natal, RN,

Brazil. 59078-970.

brasileiro@ufrnet.br

\begin{abstract}
Introduction: Soccer is the most popular and practiced sport in the world and is characterized by high intensity movements. This high demand induces several types of locomotor system injury, and one of the intrinsic factors responsible for triggering these injuries is muscle imbalances, which can occur between limbs or between muscles groups of the same limb. Objective:To evaluate the muscular performance between knee flexor/extensor groups of both limbs in professional soccer athletes: Methods: Isokinetic assessments were performed in 18 professional soccer athletes, with mean age of $26.9 \pm 3.6$ years and mean body mass index (BMI) of $23.9 \pm 1.7 \mathrm{~kg} / \mathrm{m}^{2}$.. The test protocol consisted of five concentric contractions of knee flexion and extension at angular velocity of $60 \% \mathrm{sec}, 15$ contractions at $180 \% \mathrm{sec}$ and 30 contractions at $300 \% \mathrm{sec}$ in both limbs. Test paired t-test was used to verify the torque, power, and fatigue ratio of flexors and extensors of the dominant and non-dominant knee. Results: There was no significant difference between the evaluated members related to dominance ( $p>0.05$ ). Regarding the torque ratio between flexors and extensors, we observed values below what is considered normal for this population, besides a higher fatigue index in knee flexor group when compared with the extensor group. Conclusion: No better performance was observed in the dominant limb, suggesting that, although this limb is preferred, this does not necessarily characterizes the better performance. The data also revealed an imbalance in the torque production capacity between the knee flexor and extensor groups, with an unfavorable ratio for the hamstrings, as well as a higher fatigue index in this group, which would make these muscles more susceptible to injures. Level of Evidence ll; Diagnostic studies - Investigating a diagnostic test.
\end{abstract}

Keywords: Quadriceps muscle; Muscle strength; Muscle weakness.

\section{RESUMO}

Introdução: O futebol é o esporte mais popular e mais praticado no mundo e caracteriza-se por movimentos de alta intensidade. Essa alta demanda induz diversos tipos de lesões do aparelho locomotor, e um dos fatores intrínsecos responsável por desencadear essas lesões éo desequilibrio muscular, que pode ocorrer entre os membros ou entre grupos musculares de um mesmo membro. Objetivo: Avaliar o desempenho muscular entre os grupos flexores/extensores do joelho de ambos os membros em atletas profissionais de futebol. Métodos: Foram realizadas avaliações isocinéticas em 18

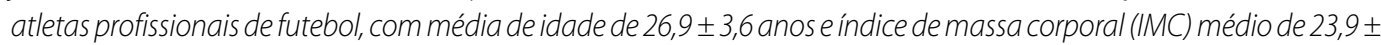
$1,7 \mathrm{~kg} / \mathrm{m}^{2}$. O protocolo do teste consistiu em cinco contrações concêntricas de flexão eextensão do joelho na velocidade angular de 60\%/s, 15 contrações a 180\%/s e 30 contrações a 300\%/s, em ambos os membros. O teste t pareado foi utilizado para verificar a razão do torque, potência e fadiga de flexores e extensores do joelho dominante e do não dominante. Resultados: Não houve diferença significativa entre os membros avaliados no que se refere à dominância $(p>0,05)$. Com relação à razão de torque entreflexores eextensores, observaram-se valores abaixo do que se considera normal para essa população, além de um maior índice de fadiga no grupo flexor quando comparado com o grupo extensor do joelho. Conclusão: Não foi observado desempenho melhor no membro dominante, sugerindo que, embora haja preferência do uso desse membro, isso não caracteriza necessariamente a melhor performance. Os dados também revelaram um desequilibrio na capacidade de produção de torque entre o grupo flexor e extensor do joelho, com razão desfavorável para os isquiotibiais, além de maior índice de fadiga nesse grupo, o que tornaria esses músculos mais suscetíveis a lesões. Nível de Evidência ll; Estudos diagnósticos - Investigação de um exame para diagnóstico.

Descritores: Músculo quadríceps; Força muscular; Fraqueza muscular.

\section{RESUMEN}

Introducción: El fútbol es el deporte más popular y más practicado en el mundo y se caracteriza por movimientos de alta intensidad. Esta alta demanda induce diversos tipos de lesiones del aparato locomotor y uno de los factores intrínsecos responsables de desencadenar esas lesiones es el desequilibrio muscular, que puede ocurrir entre los miembros o entre grupos musculares de una misma extremidad. Objetivo: Evaluar el rendimiento muscular entre los grupos flexores y extensores de la rodilla de ambas extremidades en atletas profesionales de fútbol. Métodos: Se realizaron evaluaciones isocinéticas en 18 atletas profesionales de fútbol, con promedio de edad de 26,9 3,6 años e índice de masa corporal 
(IMC) promedio de 23,9 $\pm 1,7 \mathrm{~kg} / \mathrm{m}^{2}$. El protocolo del ensayo consistió en cinco contracciones concéntricas de flexión y extensión de la rodilla a la velocidad angular de 60\%/5, 15 contracciones a 180\%/s y 30 contracciones a 300\%s, en ambas extremidades. La prueba t pareada se utilizó para verificar la razón del par de torsión, potencia y fatiga de flexores y extensores de la rodilla dominante y no dominante. Resultados: No hubo diferencia significativa entre las extremidades evaluadas en lo que se refiere a la dominancia $(p>0,05)$. Con respecto a la razón de par entre flexores y extensores, se observaron valores por debajo de lo que se considera normal para esta población, además de un mayor índice de fatiga en el grupo flexor cuando se compara con el grupo extensor de la rodilla. Conclusión: No se observó un mejor desempeño en la extremidad dominante, sugiriendo que, aunque hay preferencia del uso de esa extremidad, esto no caracteriza necesariamente un mejor rendimiento. Los datos también revelaron un desequilibrio en la capacidad de producción de par de torsión entre el grupo flexor y extensor de la rodilla, con una razón desfavorable para los isquiotibiales, además de un mayor índice de fatiga en ese grupo, lo que haría que esos músculos fueran más susceptibles a las lesiones. Nivel de evidencia ll; Estudios diagnósticos - Investigación de un examen para diagnóstico.

Descriptores: Músculo cuádriceps; Fuerza muscular; Debilidad muscular.

\section{INTRODUCTION}

Football is the most popular and most practiced sport in the world. It is characterized by high intensity movements with accelerations, decelerations, changes in direction, jumps, spins, kicks, sprints and abrupt stops $^{1}$, therefore demanding huge activity by the lower limbs. ${ }^{2}$

This high demand leads to several types of injuries in the locomotor system, making this one of the most frequent complications in practicing sport $^{3}$, and resulting in players being absent from training and competitions. These injuries usually require clinical, surgical and rehabilitation treatment, interrupting the player's activity and can lead to physical and psychological consequences, as well as having considerable impact on a team's performance. ${ }^{4,5}$

According to Fonseca et al., ${ }^{6}$ one of the intrinsic factors responsible for triggering these lesions is muscle imbalance, which may occur either between limbs or between agonist-antagonist muscles, as is mainly the case of flexor and extensor musculature in the knees., ${ }^{6,7}$ These injuries typically occur when there is a rapid active knee extension in which the eccentric action of hamstring muscles is required to decelerate the lower limb, or during rapid change from eccentric to concentric phases when this muscle becomes the hip extensor. ${ }^{8}$ In these situations, the player can exceed the limits tolerated by the muscle, which justifies the analysis of power imbalance as a factor that can lead to excessive exposure to hamstring muscle trauma. ${ }^{9}$

A widely used tool to assess muscle imbalances is the isokinetic dynamometer ${ }^{10}$. This instrument measures the conventional ratio of the flexor/extensor knee isokinetic performance, and there seems to be a consensus established among several authors that its normative value for football players is $66 \%$ at low speeds $(60 \%)$ s). 9,11,12 Furthermore, muscle evaluation by isokinetic dynamometry allows for determining useful normative data for prevention, training and rehabilitation of athletes. ${ }^{1}$ Changes in muscle torque, work and power parameters are closely related to a decrease in the athlete's functional performance, and consequently to sports injuries.

Thus, the importance of isokinetic evaluation in elite sports is highlighted more often, since this allows us to identify and quantify an athlete's performance and muscle balance. This evaluation enables planning of specific lower limb training in order to reduce specific deficiencies related to muscle function and allowing for developing prevention programs, thereby reducing the incidence of muscle injuries. ${ }^{1}$ Given the above, this study aims to evaluate muscle balance between knee flexo/extensor muscle groups from both limbs of professional football athletes using isokinetic dynamometry.

\section{MATERIALS AND METHODS}

Eighteen professional football players evaluated in the pre-season period with a mean age of $26.9 \pm 3.6$ years and mean Body Mass Index (BMI) of $23.9 \pm 1.7 \mathrm{~kg} / \mathrm{m}^{2}$ participated in the study. Players who underwent surgery in any of their lower limbs in the last year were excluded, as well as those who presented any musculoskeletal lesions in the lower limbs that made it impossible to perform the tests. The present study was approved by the Local Research Ethics Committee, under protocol No. 926,186 and after all patients signed the informed consent form.

Initially, all athletes performed a warm-up on a stationary bike (Ergo-Fit ${ }^{\circledR}$, Ergo Cycle 167, Pirmasens, Germany) with the seat adjusted to the greater trochanter height for 10 minutes with a load of $20 \mathrm{~W}$. A concentric isokinetic evaluation of the knee flexors and extensors was subsequently performed using an isokinetic dynamometer (Biodex Joint Multi-System $3^{\circledR}$, Biodex Biomedical System Inc, New York, USA) calibrated weekly according to the manufacturer's recommendations. The athletes were positioned seated on the dynamometer chair and their thighs, pelvic region and thorax were fixed by belts. The dynamometer rotation axis was aligned with the lateral epicondyle of the femur and the lever arm was adjusted in the distal region of the leg and fixed $5 \mathrm{~cm}$ above the medial malleolus of the ankle. A gravity correction factor was performed by the dynamometer with the lower limb relaxed at $30^{\circ}$ knee flexion. All these adjustments followed the recommendations by Dir. ${ }^{13}$

The test protocol consisted of five concentric contractions of knee flexion and extension at an angular velocity of $60 \%$ s, 15 contractions at $180 \%$ s and 30 contractions at $300 \%$ s in both limbs, always starting with the dominant lower limb. The whole range of movement used was $90^{\circ}$, starting at a $90^{\circ}$ flexion until complete extension of the knee. A familiarization with the equipament was performed by the participants prior each evaluation and consisted of three maximum contractions at each speed, with one-minut rest time between the series. Verbal encouragement and visual feedback were provided throughout the evaluation by the computer monitor. The analyzed variables were torque ratio at $60 \%$, power at $180 \%$ s and fatigue index at $300 \%$ of knee flexor/extensors.

\section{Statistical analysis}

Statistical analysis was performed using the software SPSS $^{\circ} 20.0$ (20.0, IBM ${ }^{\circ}$, New York, USA). First, the Kolmogorov-Smirnov test (K-S) was performed to verify data normality. It was observed that all variables presented normal distribution. 
In the inferential statistic, the paired t-test was used to verify the existence of a difference between the torque ratio, power and fatigue of knee flexors and extensors of the dominant and non-dominant limbs. A significance level of $5 \%$ and a $95 \%$ confidence interval $(95 \% \mathrm{Cl})$ were used for all statistical analyzes.

\section{RESULTS}

The results showed no significant difference between the evaluated limbs regarding dominance for the variables peak torque normalized by body weight (PT/BW), power and fatigue index.

Values below what is considered normal for this population were observed regarding torque ratio comparing the knee flexor group with the knee extensor of the same limb, while mean values of $62 \%$ were found regarding the power ratio. In addition, the fatigue index was higher in the flexor group when compared to the extensor group. (Table 1)

\section{DISCUSSION}

According to our results, the torque ratio between agonist and antagonist muscles (conventional ratio) was on average of $52 \%$, which according to Dauty et al. ${ }^{14}$ represents a high probability of injury during sports. This author observed that a ratio less than $60 \%$ evaluated in the isokinetic dynamometer at a speed of $60 \%$ s represents a $77.5 \%$ chance of knee injury in professional football athletes. In another study conducted with football athletes, Magalhães et al. ${ }^{15}$ observed similar results to this study, with a low hamstring/quadriceps ratio, ranging from 51\% to $57 \%$, demonstrating torque levels in the flexor group below what is recommended for this population.

When playing football, the knee extensor group plays an important role in the execution of most movements, in addition to being an anti-gravitational group very much required for everyday tasks. On the other hand, the flexor group is more involved in the deceleration of movements as in running and kicking for example, mainly acting in an eccentric form. ${ }^{11,16}$ In addition, there is a greater emphasis on strengthening the extensor group in training football athletes to the detriment of the flexor group, which contributes even more to this muscular imbalance.

Although a conventional ratio is still considered an important factor in assessing injury risk, it may not be sufficient to assess joint stability in the knee ${ }^{11}$. As previously stated, during the execution of functional movements such as kicking, a concentric contraction of the knee extensors and eccentric action of the flexors occurs to decelerate the lower limb in the last stages of knee extension. Thus, the ratio of the max torque of hamstring muscles in the eccentric mode and the maximum torque of the quadriceps (femoris muscle) in the concentric mode (known as functional ratio) appears to be more specific for the pattern of movement performed around the knee joint.11,15

However, an evaluation in the concentric/eccentric mode in the isokinetic dynamometer can be influenced by the learning factor, in which its results can be distorted if the individual has not previously performed training on the equipment. ${ }^{15}$ Moreover, the fact of evaluating antagonistic groups in different forms of contraction may induce errors, since it is known that the torques observed during the eccentric contractions exceed the concentric ones due to the inclusion of the elastic elements present in the muscle ${ }^{17}$. Therefore, it is currently suggested that the association of the two ratios would be the most appropriate form of evaluation. ${ }^{12}$

When evaluating the mean power at 180\% in the present study, we observed a ratio in the knee flexor/extensor muscles around $62 \%$, which demonstrates lower power of the flexor muscles when compared to extensors. Corroborating our results, Zabka et al. ${ }^{1}$ found a ratio of $63 \%$ at the speed of $240 /{ }^{\circ} \mathrm{S}$, also demonstrating lower values for the flexor group when compared to the extensor.

Power takes into account torque, angular distance and time; therefore representing the ratio of total work and the time required to carry it out. ${ }^{8}$ Thus, evaluating power emerges as an important variable to be observed in view of the sporting movements of a football player, which in most cases involve high speeds, therefore requiring good muscular power. However, despite representing functional values of the muscular condition, there are no reference values for this variable. ${ }^{8}$ Accordingly, these values are specific for each population and mainly for each sports modality. ${ }^{1}$

In relation to fatigue, a higher index was observed in the hamstring muscles when compared to the quadriceps (femoris muscle). Similar results were observed by Weber et al. ${ }^{11}$ and Carvalhais et al., ${ }^{18}$ who found a higher percentage decrease in the torque in the hamstrings compared to the quadriceps during the fatigue protocol. The fatigue index indicates the individual's ability to perform the same movement over and over again with certain resistance. The isokinetic evaluation is analyzed taking into account the difference in the work performed in the first and last third of the repetitions during the test. During the isokinetic fatigue test, Sangrier and Tourny-Chollet ${ }^{19}$ showed that the flexors reduce torque in comparison to the extensors, which also corroborates our findings.

Studies suggest that this occurs because the constitution of the fibers in these two muscle groups is different, with hamstring muscles presenting a greater amount of type II fibers compared to the quadriceps $^{19}$. Thus, hamstring muscles appear to lose more strength than the quadriceps over several consecutive intermittent movements, and are therefore more susceptible to fatigue.

The fatigue that occurs during football matches tends to decrease the performance of specific motor skills and increase injury risk. ${ }^{2}$ We emphasize that most of these abilities involve the eccentric contraction of the hamstring muscles and that $47 \%$ of the muscular injuries of this muscular group occur in the last few minutes of the second half of a game, ${ }^{2,20}$ which seems to be directly related to fatigue. Due to a larger decrease in peak torque of the hamstring muscles in comparison to the quadriceps caused by fatigue, an even greater tendency of muscle imbalance is evidenced, which may increase the injury risk, especially in the final minutes of the activity.

We found no differences when comparing dominant and non-dominant limbs for all analyzed variables. Previous studies have also not observed this difference and state that although some football-specific skills are usually performed with the preference of one limb, the results observed in the isokinetic tests suggest that the evaluated athletes are functionally and bilaterally balanced. ${ }^{11,18}$ This balance can be justified by the active participation of the non-dominant limb in passing actions and their function as a support member during kicks. ${ }^{15}$



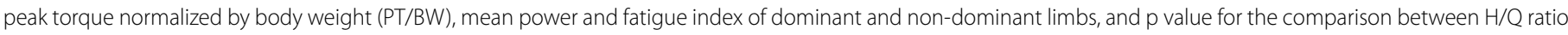
of dominant and non-dominant limbs.

\begin{tabular}{|c|c|c|c|c|c|c|c|}
\hline \multirow[b]{2}{*}{ Variables $(n=18)$} & \multicolumn{3}{|c|}{ Dominant limb } & \multicolumn{3}{|c|}{ Non-dominant limb } & \multirow[b]{2}{*}{$p$} \\
\hline & QF & $\mathrm{H}$ & H/Q RATIO & QF & $\mathrm{H}$ & H/Q RATIO & \\
\hline PT/BW (\%) & $358.6 \pm 47.9$ & $186.3 \pm 29.5$ & $52.1 \pm 5.5$ & $342 \pm 51.7$ & $176.6 \pm 24.8$ & $52.3 \pm 8.7$ & 0.89 \\
\hline Mean power (Watts) & $318.5 \pm 46.6$ & $199.4 \pm 33.1$ & $62.6 \pm 4.7$ & $313.1 \pm 44.7$ & $193.7 \pm 32.1$ & $62.0 \pm 7.3$ & 0.66 \\
\hline Fatigue index (\%) & $45.0 \pm 6.8$ & $48.4 \pm 8.0$ & $109.1 \pm 18.8$ & $43.6 \pm 7.3$ & $49.6 \pm 6.5$ & $117.5 \pm 29.2$ & 0.30 \\
\hline
\end{tabular}




\section{CONCLUSIONS}

Data from the present study reveal an imbalance in the capacity of torque production between knee flexor and extensor muscle groups, with an unfavorable ratio for hamstring muscles. Also, a higher fatigue rate was observed in this group when compared to the quadriceps, which would make these muscles more susceptible to injuries, especially in the final stages of matches. In this sense, we suggest that athletes' physical training programs include a greater volume of exercises emphasizing the flexor group in order to better balance this relationship.

Finally, better performance in the dominant limb was not observed in this group of athletes, suggesting that although there is preference for the use of the dominant limb, this does not necessarily characterize better performance.

We emphasize that the data of the present study are limited to professional football athletes and should not be used as a parameter for other sports modalities. In addition, we suggest that future studies concomitantly evaluate the functional ratio, since this variable could better evaluate the performed movement pattern when associated with a conventional ratio.

\section{ACKNOWLEDGEMENTS}

The authors acknowledge the financial support of the National Council for Scientific and Technological Development (CNPq) and the Coordination for the Improvement of Higher Education Personnel (CAPES). The authors declare that there are no conflicts of interest regarding this article.

All authors declare no potential conflict of interest related to this article.

\section{REFERENCES}

1. Zabka FF, Valente HG, Pacheco AM. Avaliação isocinética dos músculos extensores e flexores do joelho em jogadores de futebol profissional. Rev Bras Med Esporte. 2011;17(3):189-92.

2. Weber FS, Silva BG, Cardore EL, Pinto SS, Pinto RS. Avaliação isocinética da fadiga em jogadores de futebol profissional. Rev Bras Ciênc Esporte. 2012;34(3):775-88.

3. Delazeri BG, Pinto JA, Coelho RV, Liberali R. Índice de lesões musculares em jogadores profissionais de futebol com idade entre 18 e 34 anos. Rev Bras Prescr e Fisiol Exerc. 2008;2(7):18-26.

4. Hägglund M, Waldén M, Magnusson H, Kristenson K, Bengtsson H, Ekstrand J. Injuries affect team performance negatively in professional football: an 11-year follow-up of the UEFA Champions League injury study. Br J Sports Med. 2013;47:807-8.

5. Volpi P,Taioli E. The health profile of professional soccer players: future opportunities for injury prevention. J Strength Cond Res. 2012;26(12):3473-79.

6. Fonseca ST, Ocarino JM, Silva PL, Bricio RS, Costa CA, Wanner LL. Caracterização da performance muscular em atletas profissionais de futebol. Rev Bras Med Esport. 2007;13(3):143-47.

7. Fousekis K, Tsepis E, Vagenas G. Lower limb strength in professional soccer players: profile, asymmetry, and training age. J Sports Sci Med. 2010;9(3):364-73.

8. Petersen J, Hölmich P. Evidence based prevention of hamstring injuries in sport. Br J Sports Med. 2005;39(6):319-23.

9. Croisier JL, Ganteaume S, Binet J, Genty M, Ferret JM. Strength imbalances and prevention of hamstring injury in professional soccer players: a prospective study. Am J Sports Med. 2008;36(8):1469-75.

10. Goulart LF, Dias RM, Altimari LR. Variação do equilíbrio muscular durante uma temporada em jogadores de futebol categoria sub-20. Rev Bras Med Esporte. 2008;14(1):17-21.
11. Weber FS, Silva BG, Radaelli R, Paiva C, Pinto RS. Avaliação isocinética em jogadores de futebol profissional e comparação do desempenho entre as diferentes posições ocupadas no campo. Rev Bras Med Esporte. 2010;16(4):264-8.

12. Coombs R, Garbutt G. Developments in the use of the hamstring/quadriceps ratio for the assessment of muscle balance. J Sports Sci Med. 2002;1(3):56-62

13. Dvir Z. Isocinética: avaliações musculares, interpretações e aplicações clínicas. São Paulo: Manole; 2002.

14. Dauty, M, Potiron-Josse M, Rochcongar P. Identification of previous hamstring muscle injury by isokinetic concentric and eccentric torque measurement in elite soccer players. Isokinet Exerc Sci. 2003;11(3):139-44

15. Magalhães J, Oliveira J, Ascensão A, Soares JM. Avaliação isocinética da força muscular de atletas em função do desporto praticado, idade, sexo e posições específicas. Rev Port de Cien do Desp. 2001;1(2):13-21.

16. Carvalho P, Cabri J. Avaliação isocinética da força dos músculos da coxa dos futebolistas. Rev Port de Cien do Desp. 2007;1(2):4-13.

17. Lieber RL. Skeletal muscle: structure, function and plasticity. 3rd ed. Philadelphia (PA):Wiliams eWilkins; 2010.

18. Carvalhais VO, Santos TR, Araújo VL, Leite DX, Dias JM, Fonseca ST. Força muscular e índice de fadiga dos extensores e flexores do joelho de jogadores profissionais de futebol de acordo com o posicionamento em campo. Rev Bras Med Esporte. 2013;19(6):452-6.

19. Sangnier S, Tourny-Chollet C. Study of the fatigue curve in quadriceps and hamstrings of soccer players during isokinetic endurance testing. J Strength Cond Res. 2008;22(5):1458-67.

20. Woods C. Hawkins RD, Maltby S, Hulse M, Thomas A, Hodson A. The football association medical research programme: an audit of injuries in professional football: analysis of hamstring injuries. $\mathrm{Br} J$ Sports Med. 2004;38(1):36-41 